\title{
A megfelelő szájegészség megvédhet a kalciumcsatorna-blokkoló készítmények okozta gingivahyperplasia kialakulásától
}

\author{
Bán Ágnes dr. ${ }^{1}$ - Pintér Erika dr. ${ }^{2}$ - Kun József dr. ${ }^{2}$ \\ ${ }^{1}$ Pécsi Tudományegyetem, Fogorvos-tudományi Kar, Klinikai Központ, Fogászati és Szájsebészeti Klinika, \\ Parodontológiai Osztály, Pécs \\ ${ }^{2}$ Pécsi Tudományegyetem, Általános Orvostudományi Kar, Farmakológiai és Farmakoterápiai Intézet, Pécs
}

A cardiovascularis betegségek, ezen belül a magas vérnyomás a magyarországi felnőtt lakosság mintegy 40\%-át érinti. A hypertonia kezelésében gyakran alkalmazott gyógyszertípus a kalciumcsatorna-blokkolók csoportja monoterápiában vagy fix kombinációban egyaránt. Fő hatásuk a vasodilatatio, mellékhatásként gingivahyperplasiát okoznak. Tanulmányunk célja, hogy felhívjuk a kollégák figyelmét annak fontosságára a mindennapi gyakorlatban, hogy a kalciumcsatorna-blokkolók szedése mellett kialakuló gingivahyperplasia szoros korrelációt mutat a páciens fogazati állapotával, a fogak és a fogpótlások felületén található plakk mennyiségével. A már kialakult gingivahyperplasia megnehezíti a páciens számára az individuális fogtisztítást, tovább növeli a plakkfelhalmozódást, elősegítve ezzel olyan Gram-negatív baktériumok plakkban történő felszaporodását, amelyek növelik az ínymegnagyobbodást, és rizikótényezőként szerepelhetnek további cardiovascularis betegségekben. Az esetek jelentős százalékában a kalciumcsatorna-blokkoló terápia mellett is megőrizhető és hosszú távon fenntartható a gingiva egészséges, hyperplasiamentes állapota megfelelő individuális szájhigiénia és professzionális fogászati beavatkozások elvégzése esetén. A betegek szájegészségének megőrzése érdekében fontosnak tartanánk a belgyógyász kollégák és a fogorvosok közötti szorosabb együttmúködést.

Orv Hetil. 2018; 159(29): 1183-1187.

Kulcsszavak: kalciumcsatorna-blokkoló, gingivahyperplasia, szájhigiénia, dentális plakk

\section{Proper oral health can protect from developing gingival hyperplasia induced by calcium channel blockers}

Cardiovascular diseases including hypertension affect $40 \%$ of the adult population in Hungary. Calcium channel blockers are frequently prescribed for the treatment of hypertension either in monotherapy or in fixed-combination therapy. Their main effect is vasodilatation with gingival hyperplasia as a side effect. Our aim is to draw our colleagues' attention to the practical importance of the fact that calcium channel blocker-induced gingival hyperplasia correlates closely with the dental status and the quantity of plaque on the surface of teeth and dental implants. Once established, gingival hyperplasia makes it more difficult for the patient to maintain individual tooth cleaning and increases plaque formation. Thus proliferation of Gram-negative bacteria is enabled in the plaque which promotes gingival overgrowth and can pose a risk factor for further cardiovascular diseases. If proper individual oral hygiene and professional interventions are carried out, healthy and hyperplasia-free gingival state can be sustained in the long term in most cases, even with calcium channel blocker therapy. In order to protect patients' oral health, a closer cooperation of internists and dentists would be desirable.

Keywords: calcium channel blocker, gingival hyperplasia, oral hygiene, dental plaque

Bán Á, Pintér E, Kun J. [Proper oral health can protect from developing gingival hyperplasia induced by calcium channel blockers]. Orv Hetil. 2018; 159(29): 1183-1187.

(Beérkezett: 2018. február 13.; elfogadva: 2018. március 5.) 


\section{Rövidítések}

$\mathrm{ACE}=$ (angiotensin-converting enzyme $)$ angiotenzin-konvertáló enzim; BOP $=$ (bleeding on probing) ínyvérzési index; HLA = humán leukocyta antigén; IBD = (inflammatory bowel disease) gyulladásos bélbetegség; IFN = interferon; IL = interleukin; KK = Klinikai Központ; LPS = lipopoliszacharid; PTE = Pécsi Tudományegyetem; TGF $\beta=$ (transforming growth factor beta) transzformáló növekedési faktor-béta; TNF = tumornekrózis-faktor

A szív- és érrendszeri betegségek, ezen belül a magas vérnyomás a magyarországi felnőtt lakosság mintegy 40\%-át érinti [1]. A hypertonia kezelésében leggyakrabban alkalmazott kalciumcsatorna-blokkolók az 1960-as évek óta vannak jelen a gyógyszerkészletben. Fő hatásuk a vasodilatatio, ezért antiischaemiás, antianginás és antihipertenzív szerként használatosak [2]. Szájüregi mellékhatásról, a gingivaduzzanatról 1984-ben jelentek meg az első közlemények, melyek Lederman, illetve Ramon és mtsai nevéhez füződnek $[3,4]$.

A legtöbb irodalom a dihidropiridinek csoportjába tartozó nifedipin mellékhatásairól szól, mely a legkorábban és a legszélesebb körben alkalmazott kalciumcsatorna-gátló volt. Klinikai multicentrikus tanulmányok felhívták a figyelmet, hogy a gyors felszívódású, rövid hatású dihidropiridineknek, különösen a nifedipinnek jelentős kockázati tényezői vannak (cardiovascularis mortalitás) [5]. Az elnyújtott hatástartamú készítmények, mint az amlodipin alkalmazása ezért előtérbe került mind monoterápiában, mind fix kombinációban, például ACE-gátló készítményekkel, angiotenzinreceptor-antagonistákkal, illetve béta-blokkolókkal [6].

Az Országos Egészségpénztár adatbázisa alapján az orvosok által társadalombiztosítási támogatással rendelt kalciumcsatorna-blokkolók között az amlodipinreceptek aránya 2013 decemberére 87,12\%-ra nőtt. A kiváltott dobozok mennyiségének pedig több mint 40\%-a $\mathrm{Ca}^{++}$ csatorna-blokkoló fix kombinációt tartalmazott [2]. Fix kombinációkban, az önállóan alkalmazott ACE-gátló kezeléshez képest javul a betegek terápiahüsége, hatékonyabban érhetők el a vérnyomáscélértékek, valamint hosszabb távon csökkenthető a cardiovascularis szövődmények kialakulásának kockázata $[7,8]$. A fokozottabb elterjedés következtében a gingivahyperplasia gyakorisága az amlodipint szedő páciensek körében szakirodalmi adatok szerint a korábbi néhány százalékról 10\%-ra nőtt [9, 10]. Számos közlemény talált korrelációt az ínymegnagyobbodás és a dihidropiridinszerkezetű $\mathrm{Ca}^{++}$-csatorna-blokkolók újabb generációja között is, mint a felodipin, a nikardipin, a manidipin, míg a cilnidipint eddig még nem hozták összefüggésbe a gingivahyperplasiával [11-14].

Tanulmányunk célja, hogy felhívjuk a kollégák figyelmét annak fontosságára a mindennapi gyakorlatban, hogy a $\mathrm{Ca}^{++}$-csatorna-blokkolók szedése mellett kialakuló gingivahyperplasia szoros korrelációt mutat a páciens fogazati állapotával és a fogak felületén található plakk mennyiségével (plakkindex). A fogorvossal való együttmúködéssel megelőzhető, illetve kezelhető a mellékhatás.

\section{Megbeszélés}

A Ca ${ }^{++}$-csatorna-blokkolók ínyduzzanatot okozó hatásában a pontos patomechanizmus nem tisztázott, de a szakirodalmi adatok alapján kijelenthető, hogy több etiológiai faktor egyidejű jelenléte szükséges az elváltozás kialakulásához. A mellékhatásként fellépő gingivahyperplasiáért nem lehet kizárólagosan a kalciumcsatornablokkoló gyógyszerek szedését felelőssé tenni. A legtöbb tanulmány nem talált összefüggést az amlodipin alkalmazott dózisa és a hyperplasia súlyossága között [15]. Felelőssé tehető rizikótényezők: dentális plakk, plakkretenciós tényezők, rossz szájhigiénia, egyéni hajlam. Az ínyduzzanat előfordulása szignifikáns mértékben korrelál a plakk mértékével és a gingivaindex értékével [13, 16, 17]. A betegség klasszifikációs rendszerében a plakk kofaktorként szerepel [18], az általa okozott gyulladással arányos a gingivahyperplasia súlyossága $[16,19]$. Néhány tanulmány szerint férfiaknál nagyobb valószínúséggel alakul ki az ínyduzzanat, míg mások nem találtak nemek közötti különbséget [20].

$\mathrm{Az}$ amlodipin, illetve a $\mathrm{Ca}^{++}$-csatorna-blokkolók hatása az ínyduzzanat patogenezisében nem tisztázott. Feltételezik, hogy a különböző gyógyszerek eltérően befolyásolják a fibroblastok sejtes és molekuláris szintü tulajdonságait [21]. A dentális plakk által okozott gyulladás modulálhatja a gyógyszer-fibroblast kölcsönhatást, de ezenkívül nem gyulladásos mechanizmusok is okolhatók. Az irodalomban három fó tényezőt emelnek ki [13, 22-24]:

1. A kollagénhomeosztázis megváltozása. A megnövekedő kötőszöveti állományban az anyagcsere a kollagénrostok felhalmozódása felé tolódik el (a kollagenázaktivitás csökkenése, a kollagénszintézis növekedése). Ebben a T-sejtekben, fibroblastokban történő citoszol-Ca ${ }^{++}$-csökkenés közvetlenül is szerepet játszhat, illetve a folsavfelvétel csökkenésén keresztül közvetve magyarázhatók a kötőszövet anyagcseréjében kialakuló patológiás változások [23]. Felvetődhet a kérdés, hogy a szisztémás keringésbe jutó gyógyszerek miért csak az íny szövetszaporulatát okozzák. Moffitt és mtsai összefoglalója [25] alapján ennek hátterében eltérő válaszkészségű fibroblastfenotípusok vagy az íny fibroblastjainak alapszinten magas kollagéntermelése (turnover) állhat, továbbá a nifedipin, amlodipin koncentrálódhat a megnagyobbodott ínyszövet crevicularis folyadékában. Már az 1980-as években azonosítottak gingivafibroblast-szubpopulációk közötti jelentős különbségeket, ami magyarázhatná a gyógyszerválaszban mutatkozó variabilitást. Az in vitro kísérletes eredmények azonban nem vezettek klinikai fenotípus azonosításához, amellyel a fibroblastok fogékonysága magyarázható lenne [23, 26, 27]. 
2. Genetikai prediszpozició. A betegek kis hányadában tehát a fibroblastok fogékonyabbak a $\mathrm{Ca}^{++}$-csatorna-antagonisták hatására, ez kapcsolatban állhat az MHC II. antigénekkel. A HLA-B37 szignifikáns kockázati tényező az ínymegnagyobbodás kialakulásában, más HLA-k (például HLA-DR2) esetében ez még nem kellően tisztázott [27-29]. A HLA-k szerepére gingiva-szövetszaporulatban nincs elfogadott magyarázat, a molekuláris mimikri jelensége vagy a lymphocytafunkciók eltérése mellett felmerült, hogy pusztán genetikai kapcsoltság (linkage disequilibrium) áll fenn a 6-os kromoszómán a HLA- és a hyperplasiában szerepet játszó nem-HLA-gének között [27]. A multidrug resistance-1- (MDRlvagy ABCBl-) gén G2677T/A-polimorfizmusai összefüggést mutatnak a kalciumcsatorna-blokkolók indukálta gingivahyperplasia mértékével. A mélyebb gingivatasak kialakulása a kalciumcsatorna-blokkolót szedő betegekben szignifikánsan korrelál az MDRl G2677T/ A-polimorfizmusaival. Az MDRl-gén terméke az ínyérendothelben termelődő P-glikoprotein (P-gp), amelyet a Ca-antagonisták különböző mértékben gátolnak, és amelynek szerepe lehet a gyulladásos folyamatokban is [30]. A P-gp az ABC-transzporterek közé tartozó, adenozin-trifoszfát-függó efflux pumpa a membránban, amelynek a sejtek xenobiotikumok elleni védelmében van szerepe. Meisel és mtsai összefoglalója [30] alapján a $\mathrm{Ca}^{++}$-antagonisták által fokozott gyulladás a termelődő citokineken keresztül növeli a P-gp-expressziót és -funkciót. Ugyanakkor maga a P-gp is modulálhatja a gyulladásos folyamatokat, a citokinek kiváltotta szöveti átépülést. A gingivahyperplasiára hajlamosító MDRl-genotípusok esetén magasabb a szisztémás gyulladásra utaló szérummarkerek szintje. A pontos mechanizmus kevéssé ismert, a $\mathrm{Ca}^{++}$-antagonisták közvetlen gátló hatásának kisebb súlyt tulajdonítanak. A gingivahyperplasia kialakulásakor a P-gp-izoformák különbözőképpen modulálhatják a gyulladásfokozó gyógyszerhatásokat, a gyulladásos bélbetegségekhez (IBD) hasonlóan. Egy másik feltevés szerint a csökkent P-gp-aktivitás a kollagénlebontást serkentő interleukin-2 (IL2) szintjét mérsékli [30]. A citokróm P450 részt vesz a nifedipin és számtalan más gyógyszervegyület metabolizmusában. Az enzim öröklött polimorfizmusa befolyásolja ezen gyógyszerek szérum- és szöveti koncentrációját, így gingivahyperplasiát fokozó hatását [27].

A genetikai háttér magyarázatot adhat arra, hogy a páciensek kis részében tökéletes szájhigiénia mellett is kialakulhat az ínyhyperplasia.

3. A dentális plakk gyulladást és további kötöszöveti proliferációt okoz. A dentális plakk egy bakteriális biofilm, amely komplex mikrobiális közösséget alkot. A baktériumok egymásra rétegződő kolonizációja és koaggregációja a gazdaszervezet, vagyis a beteg fogékonysága, a patogén és „protektív” baktériumfajok egyensúlya által meghatározott egységként funkcionál [31]. A gyulladást indukáló plakk és a crevicularis folyadékban feldúsuló gyógyszermolekulák szinergikus módon serkentik citoki- nek termelődését, mint az IL1 $\beta$, IL6, valamint a transzformáló növekedési faktor-béta (TGFß). Ezek hozzájárulnak a gingivafibroblastok proliferációjához és kollagénszintéziséhez. Ahogy már a 2-es pontban utaltunk rá, a kalciumcsatorna-blokkolókkal kezelt betegekben szignifikánsan mélyebb gingivatasak alakul ki a gyógyszert nem szedő kontrollcsoporthoz képest [30].

Számos szakirodalmi adat bizonyítja, hogy a plakkmennyiség csökkentésével a már kialakult gingivahyperplasia bizonyos mértékben javítható, de kifejezett esetekben parodontológiai mútéti beavatkozások is szükségesek lehetnek [32-34]. A szerzők praxisából hozott jellemző példa az az 55 éves férfi páciens, aki extrém méretû ínyduzzanattal, kellemetlen szájszaggal és ennek következtében életminőség-romlással érkezett a PTE KK Fogászati és Szájsebészeti Klinika Parodontológiai Osztályára (1. ábra). Az igényes, ápolt páciens elmondása szerint több fogorvost is felkeresett panaszával, melyet gyógyszer okozta gingivahyperplasiának diagnosztizáltak. Háziorvosához utalták kalciumcsatorna-blokkoló gyógyszerének cseréjére, de ellátásban nem részesítették, és az évek alatt fokozatosan kialakult ínyduzzanat egyre fokozódott, annak ellenére, hogy naponta többször is próbálta tisztítani a fogait.

Anamnéziséből kiderül, hogy 13 éve szed hypertoniájára kalciumcsatorna-blokkolót, 10 éven át $5 \mathrm{mg}$ amlodipinterápiában részesült, ezt követően egy másik gyártótól $10 \mathrm{mg}$ amlodipint szedett.

$\mathrm{Az}$ intraoralis vizsgálat során az alsó állcsonton a fogak koronai részének több mint felét, a felső állcsonton a fogak gingivalis egyharmadát befedő, kemény tapintatú, fibroticus duzzanat volt látható. Az átlagos klinikai szondázási mélység 8 és $12 \mathrm{~mm}$ között volt, a BOP (ínyvérzési index) 40\% körül mozgott. A valódi tapadásveszteség miatt a tasakredukció az oki terápiát követően mucoperiostealislebeny-képzés és fordított belső ferde gingivectomia kombinációjával történt. A kezelés során a reménytelen prognózisú fogak extrakciója (alsó metszők, jobb alsó második molaris), a régi koronák elálló széleinek elsimítása (alsó praemolarisok), a jobb alsó má-

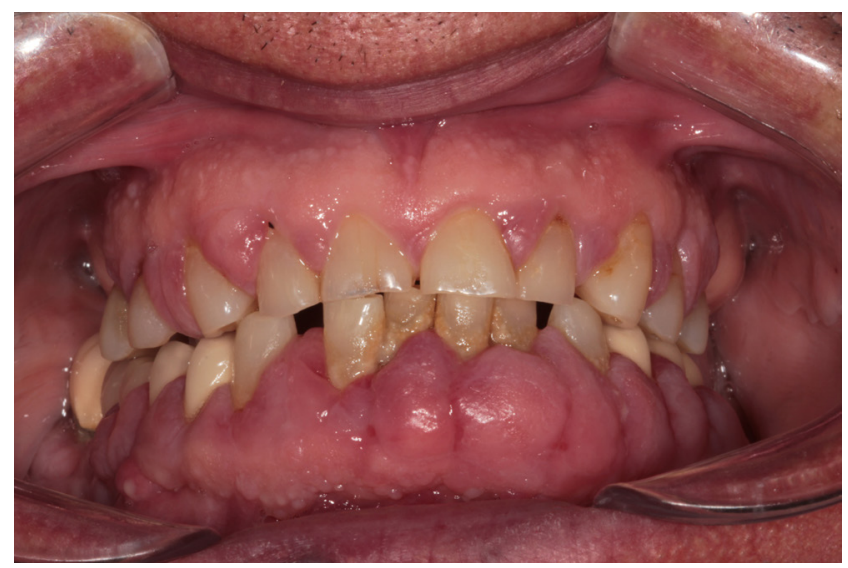

\begin{tabular}{l|l} 
1. ábra & 55 éves, kalciumcsatorna-blokkoló gyógyszert szedő férfi páci-
\end{tabular} ens, extrém méretű gingivahyperplasiával, plakkal 


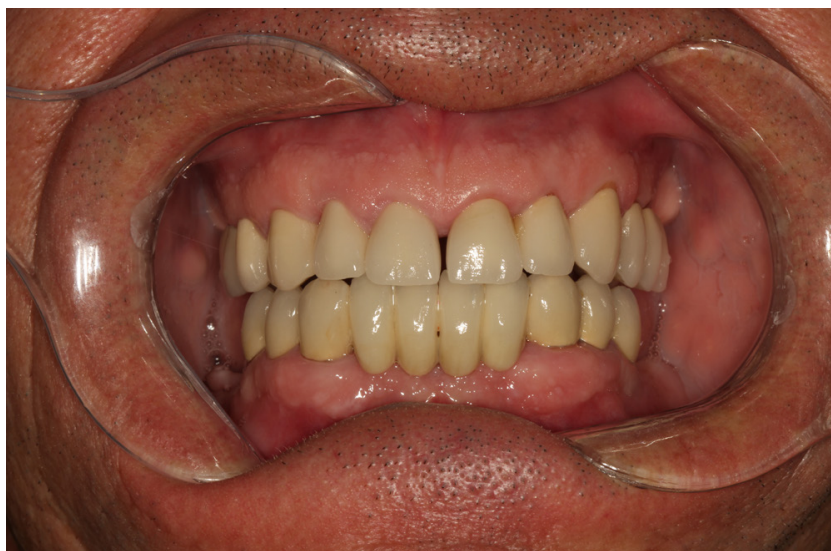

2. ábra

A páciens komplex parodontológiai és protetikai ellátás után másfél évvel a kalciumcsatorna-blokkoló terápia folytatása mellett recidívamentes állapotban

sodik kisőrlő endodontiai ellátása, a bal alsó második kisőrlő paro-endo laesiójának komplex ellátása (endodontia és regeneratív terápia) megtörtént. A hiányzó fogakat fémkerámia híddal pótoltuk.

A terápia során komplikáció nem lépett fel, a gyors és eseménytelen sebgyógyulást a páciens szájhigiéniás együttmúködése nagymértékben segítette, ennek tulajdoníthatóan a kalciumcsatorna-blokkoló terápia folytatása ellenére posztoperatív recidíva az elmúlt 1,5 évben nem lépett fel (2. ábra).

A már kialakult ínyduzzanatban fóként olyan Gramnegatív patogén baktériumok szaporodnak fel, amelyek a krónikus paradontitisre jellemzőek [31, 35]. A baktériumflóra gyakori elemei között található az Eubacterium alactolyticum, Campylobacter concisus, Capnocytophaga spp. (C. ochracea, C. sputigena, C.gingivalis), Fusobacterium nucleatum és $F$. varium $[25,36]$. A Gram-negatív sejtfal lipopoliszacharid (LPS)-tartalma serkenti makrofágok és más immunsejtek érését (priming), valamint fokozza gyulladásos citokinek (például IL1 $\beta$, tumornekrózisfaktor-alfa $[\mathrm{TNF} \alpha]$, interferon-gamma $[\mathrm{IFN} \gamma])$ termelődését [37], pozitív visszacsatolásként tovább növelve a gingivahyperplasiát. Ezek a baktériumok rizikótényezőt jelenthetnek cardiovascularis betegségek kialakulásában, illetve progressziójában is, mint például atherosclerosis, szívinfarktus és stroke [37-39].

$\mathrm{Az}$ íny fibroblastjai és a megjelenő immunsejtek közötti összetett interakció irányítja a gyulladást. A fibroblastantigén CD40 (a TNF $\alpha$-receptorcsalád tagja) és az immunsejteken jelen lévő ligandja, a CD40L közvetlen sejt-sejt kontaktust, a két sejttípus kölcsönös aktiválását teszi lehetővé. Ennek eredményeként az immunsejtek citokinfelszabadítása, a fibroblastok proliferációja és kemokintermelése növekszik, ez a gyulladásos folyamatok amplifikációjához vezet [40].

\section{Következtetés}

Az esetek jelentős százalékában a kalciumcsatorna-blokkoló terápia mellett is megőrizhető és hosszú távon fenntartható a gingiva egészséges, hyperplasiamentes állapota megfelelő individuális szájhigiénia és professzionális fogászati beavatkozások elvégzése esetén. A betegek szájegészségének megőrzése érdekében fontosnak tartanánk a belgyógyász kollégák és a fogorvosok közötti szorosabb együttmúködést. A kalciumcsatorna-blokkolók alkalmazásával párhuzamosan a mellékhatás megelőzésére koncentrálva javasolt lenne a plakkretenciós tényezők eltávolítása, illetve a szájhigiénia javítása. A már kialakult gingivahyperplasia tovább rontja a szájhigiéniát, megnehezíti a páciens számára az individuális fogtisztítást, tovább növeli a plakkfelhalmozódást, elősegítve ezzel a Gram-negatív baktériumok plakkban történő felszaporodását. Ez rizikótényező cardiovascularis betegségek kialakulásában, illetve tovább növelheti a gingivahyperplasiát.

Anyagi támogatás: A közlemény megírása a „PEPSYS” GINOP-232-15-2016-00050. számú pályázat támogatásával történt.

Szerzôi munkamegosztás: A szerzők egyenlő arányban vettek részt a kézirat megírásában. A cikk végleges változatát mindhárom szerző elolvasta és jóváhagyta.

Érdekeltségek: A szerzőknek nincsenek érdekeltségeik.

\section{Irodalom}

[1] Health status (2003-2016) - Social progress indicator system. [Egészségi állapot (2003-2016) - A társadalmi haladás mutatószámrendszere.] Központi Statisztikai Hivatal, Budapest, 2016; http://www.ksh.hu/thm/2/indi2_8_1.html (accessed: January 27, 2018). [Hungarian]

[2] Barna I, Gyurcsányi A. Increase in the use of Ca-channel blockers in fixed-dose combination in domestic medical practice between 2007-2013. [A kalciumcsatorna-blokkolók fix dózisú kombinációban történő alkalmazása növekedésének jelentősége a hazai orvosi gyakorlatban a 2007-2013 közötti időszakban.] Hyperton Nephrol. 2015; 19: 11-17. [Hungarian]

[3] Lederman D, Lumerman H, Reuben S, et al. Gingival hyperplasia associated with nifedipine therapy. Report of a case. Oral Surg Oral Med Oral Pathol. 1984; 57: 620-622.

[4] Ramon Y, Behar S, Kishon Y, et al. Gingival hyperplasia caused by nifedipine - a preliminary report. Int J Cardiol. 1984; 5: 195206.

[5] Pahor M, Psaty BM, Alderman MH, et al. Health outcomes associated with calcium antagonists compared with other first-line antihypertensive therapies: A meta-analysis of randomised controlled trials. Lancet 2000; 356: 1949-1954.

[6] Gyurcsányi A, Barna I. Overview of changes in the use of the cardiovascular system products based on National Health Insurance data. [Áttekintés a cardiovascularis rendszerre ható készítmények felhasználásának változásáról az OEP gyógyszerforgalmi adatok alapján.] Hyperton Nephrol. 2016; 20: 109-113. [Hungarian]

[7] Vértes A, Szabados E. Cardiovascular prevention - 2016. [Cardiovascularis prevenció - 2016.] Orv Hetil. 2016; 157: 15261531. [Hungarian].

[8] Simonyi G, Ferenci T, Medvegy M, et al. One year persistence of free and fixed dose combinations of perindopril/amlodipine. 
[A perindopril/amlodipin szabad és fix kombinációk egyéves terápiahúsége.] Orv Hetil. 2017; 158: 1421-1425. [Hungarian]

[9] Jorgensen MG. Prevalence of amlodipine-related gingival hyperplasia. J Periodontol. 1997; 68: 676-678.

[10] Kalburgi V, Raghuwanshi S, Lavanya N, et al. Prevalence of gingival hyperplasia secondary to amlodipine. Indian J Dent Adv. 2015; 7: 168-172.

[11] Takahara A. Cilnidipine: A new generation $\mathrm{Ca}^{2+}$ channel blocker with inhibitory action on sympathetic neurotransmitter release. Cardiovasc Ther. 2009; 27: 124-139.

[12] Mohanty M, Tripathy KP, Srakar S, et al. Evaluation of safety and tolerability of amlodipine and cilnidipine - A comparative study. Sch J App Med Sci. 2016; 4: 2884-2894.

[13] Livada R, Shiloah J. Calcium channel blocker-induced gingival enlargement. J Hum Hypertens. 2014; 28: 10-14.

[14] Babu KA. Assessment of efficacy of amlodipine with cilnidipine in hypertensive patients: A comparative study. Int J Contemp Med Res. 2017; 4: 956-958.

[15] Ono M, Tanaka S, Takeuchi R, et al. Prevalence of amlodipineinduced gingival overgrowth. Int J Oral Med Sci. 2010; 9: 96100 .

[16] Ellis JS, Seymour RA, Steele JG, et al. Prevalence of gingival overgrowth induced by calcium channel blockers: A communitybased study. J Periodontol. 1999; 70: 63-67.

[17] Karnik R, Bhat KM, Bhat GS. Prevalence of gingival overgrowth among elderly patients under amlodipine therapy at a large Indian teaching hospital. Gerodontology 2012; 29: 209-213.

[18] Armitage GC. Development of a classification system for periodontal disease. Ann Periodontol. 1999; 4: 1-6.

[19] Ono M, Ono N, Hasegawa K, et al. Incidence of gingival overgrowth caused by calcium channel blockers. Oral Ther Pharmacol. $2008 ; 27$ : 79-85.

[20] Haytac MC, Ozcelik O, Mariotti A. Periodontal disease in men. Periodontology 2000. 2013; 61: 252-265.

[21] Trackman PC, Kantarci A. Molecular and clinical aspects of drug-induced gingival overgrowth. J Dent Res. 2015; 94: 540546.

[22] Straka M, Varga I, Erdelský I, et al. Drug-induced gingival enlargement. Neuro Endocrinol Lett. 2014; 35: 567-576.

[23] Brown RS, Arany PR. Mechanism of drug-induced gingival overgrowth revisited: a unifying hypothesis. Oral Dis. 2015; 21: e51e61.

[24] Fardal $\varnothing$, Lygre H. Management of periodontal disease in patients using calcium channel blockers - gingival overgrowth, prescribed medications, treatment responses and added treatment costs. J Clin Periodontol. 2015; 42: 640-646.

[25] Moffitt ML, Bencivenni D, Cohen RE. Drug-induced gingival enlargement: an overview. Compend Contin Educ Dent. 2013; 34: 330-336.
[26] Kantor ML, Hassell TM. Increased accumulation of sulfated glycosaminoglycans in cultures of human fibroblasts from phenytoin-induced gingival overgrowth. J Dent Res. 1983; 62: 383-387.

[27] Seymour RA, Ellis JS, Thomason JM. Risk factors for drug-induced gingival overgrowth. J Clin Periodontol. 2000; 27: 217223.

[28] Pernu HE, Knuuttila ML, Huttunen KR, et al. Drug-induced gingival overgrowth and class II major histocompatibility antigens. Transplantation 1994; 57: 1811-1813.

[29] Cebeci I, Kantarci A, Firatli E, et al. Evaluation of the frequency of HLA determinants in patients with gingival overgrowth induced by cyclosporine-A. J Clin Periodontol. 1996; 23: 737742.

[30] Meisel P, Giebel J, Kunert-Keil C, et al. MDRl gene polymorphisms and risk of gingival hyperplasia induced by calcium antagonists. Clin Pharmacol Ther. 2006; 79: 62-71.

[31] Sbordone L, Bortolaia C. Oral microbial biofilms and plaquerelated diseases: microbial communities and their role in the shift from oral health to disease. Clin Oral Investig. 2003; 7: 181188.

[32] Arun JL, Rani S, Manoj Kumar P. Adverse drug reactions associated with anti-hypertensive drugs and its management. Int J Pharm Sci Rev Res. 2016; 41: 33-37.

[33] Lafzi A, Farahani RM, Shoja MM. Amlodipine-induced gingival hyperplasia. Med Oral Patol Oral Cir Bucal 2006; 11: E480E482.

[34] Sanz M. Current use of calcium channel blockers (CCBs) is associated with an increased risk of gingival hyperplasia. J Evid Based Dent Pract. 2012; 12: 147-148.

[35] Holt SC, Bramanti TE. Factors in virulence expression and their role in periodontal disease pathogenesis. Crit Rev Oral Biol Med. 1991; 2: 177-281.

[36] Nakou M, Kamma JJ, Andronikaki A, et al. Subgingival microflora associated with nifedipine-induced gingival overgrowth. J Periodontol. 1998; 69: 664-669.

[37] Herzberg MC, Meyer MW. Dental plaque, platelets, and cardiovascular diseases. Ann Periodontol. 1998; 3: 151-160.

[38] Grau AJ, Becher H, Ziegler CM, et al. Periodontal disease as a risk factor for ischemic stroke. Stroke 2004; 35: 496-501.

[39] Derdák D, Vadócz R, Kivovics P, et al. The effect of dental biofilm on the general health condition. [A dentális biofilm hatása az általános egészségi állapotra.] Magy Fogorv. 2016; 286-290. [Hungarian]

[40] Fries KM, Sempowski GD, Gaspari AA, et al. CD40 expression by human fibroblasts. Clin Immunol Immunopathol. 1995; 77: $42-51$.

(Kun József dr., Pécs, Szigeti út 12., 7624 e-mail: jkun80@gmail.com)

\section{"Prima digestio fit in ore." (Az első emésztés a szájban történik.)}

